J Klee

Lecturer, Department

of Historical Studies,

University of

Johannesburg.

Email: jklee@uj.ac.za

ES van Eeden

Professor of History,

School of Social Siences, North-West University.

Email: Elize.VanEeden(a)

nwu.ac.za

DOI: https://dx.doi.

org/10.18820/24150509/

JCH43.v2.5

ISSN 0258-2422 (Print)

ISSN 2415-0509 (Online)

Journal for Contemporary

History

2018 43(2):78-95

(c) Creative Commons With Attribution (CC-BY)

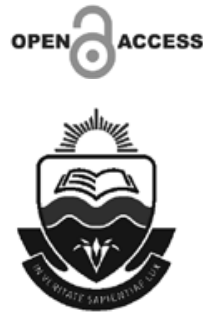

\section{CONTEMPLATING THE APPROACH OF RAU'S FOUNDERS TOWARDS RADICALLY TRANSFORMING AFRIKAANS SPEAKER IDENTITY IN TAKING ECONOMIC RESPONSIBILITY}

\begin{abstract}
This discussion on the former Rand Afrikaans University (RAU) covers the founding years of the University from 1955 to 1975. What should become clear from the contemplations is that the establishment of RAU in 1968 (today the University of Johannesburg), was not driven by the increase in the population of white Afrikaans speakers on the Witwatersrand or to act as a force against the liberal influences of the University of the Witwatersrand (Wits). The philosophy behind the establishment of RAU was mainly to reposition and empower white Afrikaans speakers with the education required to ensure that they could take their place in particularly the Witwatersrand as economic heartland of South Africa, and South Africa in general. Part of this approach by the founders was to create and develop RAU to become the most modern Afrikaans university of its time, providing quality teaching and learning of a high local and international standards. The prominence of being a university driven by specific ideals contributed to the forming of the Afrikaans speaker's identity in education and the national economy. As examples, this discussion mainly emphasises some new teaching methods introduced at the time, visibly blending with a refreshed view on the architectural design to accommodate the philosophical ideals envisioned for RAU. The founders' vision was for RAU to become an educational instrument towards transforming white Afrikaans speaker identity within a modernised context.
\end{abstract}

Keywords: Teaching methods; teaching systems; philosophy; RAU; modernising; industrial heartland of South Africa; architectural design; universities idea; identity.

Sleutelwoorde: Onderrigmetodes; onderrigstelsels; filosofie; RAU; modernisering; industriële hartland van Suid-Afrika; argitektoniese ontwerp; universitêre begrip; identiteit 


\section{INTRODUCTION}

The pioneering history of the Rand Afrikaans University (RAU) covers a period of 13 years. It culminated in the establishment of RAU in 1968. During the course of this period, the founding fathers envisioned an Afrikaans university that would become a vehicle for driving the advancement and modernisation ${ }^{1}$ of an Afrikaner identity. ${ }^{2}$ In material terms, their thinking crystallised in the creation of a physical structure, which had a unique modern architectural design ${ }^{3}$, worlds apart from the temporary location in the old South African Breweries buildings in Ameshoff Street in Braamfontein, where the institution commenced operating on 24 February 1968, ${ }^{4}$ and which also affected their thoughts regarding new teaching methods. These would become valued reflexive intellectual statements contributing to the building blocks of the new, modern university. Its physical appearance would reflect the philosophy shared by its founders. Ultimately, the university would represent the realisation of a dream through the expression of an idea with which many white Afrikaans speakers on the Witwatersrand could associate. ${ }^{5}$

The establishment of RAU took place against the backdrop of a global increase in the number of universities since the 1960s. Universities were established for a number of reasons, including those of an economic, political and social nature. The establishment of universities since the 1960s, however, introduced a turning point or shift whereby universities would no longer be

1 The words modern, modernising or modernisation have been used since the 1960 s by academics researching different themes relating to the university to describe the characteristics of new universities established during this time and subsequently. It refers to an institution that belongs to a new era of new approaches, beliefs, ideas and interpretations, an institution that changes with the demands of the time.

2 University of Johannesburg/Rand Afrikaans University Archives (UJ/RAU), Johannesburg, PJ Meyer Collection, File C1/1: Die beplanning van die Randse Afrikaanse Universiteit, p.1; also see UJ/RAU - collection: J Cronje Collection - File A 36/4: Prof. G van N Viljoen titled Vestiging, geboubeplanning en ontstaansgeskiedenis, Speech by Viljoen at the Municipality of Brakpan on 12 October 1969, titled Die Randse Afrikaanse Universiteit en die Munisipaliteit van Brakpan, p. 1. The term Afrikaner identity in this article refers to the moulding of a new image for the Afrikaner, which represents the Afrikaner accepting and becoming part of the modern world's thinking and approaches, and in which the new Afrikaner re-thinks his identity, accepting the modern but also advancing his culture, beliefs and language.

3 UJ/RAU Archives, Randse Afrikaanse Universiteit Collection, File A 34/1, Universiteit en Gemeenskap, Toespraak deur G van N Viljoen voor die Johannesburgse Afrikaanse Sakekamer, 21 Maart 1967, p. 1.

$4 \quad J C$ van der Walt, "Gerrit Viljoen se RAU: Toe en vandag". In: B Louw en F van Rensburg (reds.), Bestendige binnevuur: perspektiewe op Gerrit Viljoen by geleentheid van sy een-en-sewentigste verjaarsdag op 11 September 1997 (Kaapstad: Tafelberg, 1997), p. 91.

5 UJ/RAU Archives, Randse Afrikaanse Universiteit Collection, File A 34/1: Universiteit en Gemeenskap, Toespraak G van N Viljoen, Johannesburgse Afrikaanse Sakekamer, 21 Maart 1967, p. 1. 
established for the elite minority, but as institutions catering for the needs of the masses. The establishment motivation for RAU was driven by the need to advance the white Afrikaans speaker economically and ideologically in his mother tongue. ${ }^{6}$

As plans for developing a modern Afrikaans university started falling into place, the founders gave careful thought to elements constituting a notional university. This process ${ }^{8}$ was characterised by thorough research, data gathering, debate and conversation based on existing and new ideas relating to universities. In this regard, the first rector, Prof. G van N Viljoen, embarked on an overseas visit to conduct research into universities in other parts of the world. ${ }^{9}$ This was followed by another visit abroad by the appointed architects, wO Meyer and J van Wijk, who gathered information on planning and developing to create RAU's architectural structure and facilities. ${ }^{10}$ The founders' subsequent overseas visit was a concerted effort to meet with stakeholders representing different universities. The South African team engaged in meetings and functions to secure information on matters related to the founding rationale of institutions; the aims and functions of the academic programmes; the roles of staff and students; and the physical planning of universities."

RAU's founders were determined to ensure that the new university would be representative of the ultimate expression of their "ideas" - ideas that would inculcate the Western university tradition. PJ Meyer (inaugural chair of the RAU Council), a leading founding member, many years later recalled that the university had to be based on the Western university tradition and, more specifically, on Dutch and German models.12 This simply meant that the managerial, administrative and academic styles had to be similar to German and Dutch counterparts in terms of the roles of the chancellor and rector (vice-chancellor), deans of faculties and heads of academic departments. Academic courses and degrees would also follow the salient principles of Western university tradition. ${ }^{13}$ Furthermore, dreams visualised at the time for the new university were that it would be impressive, modern, and unique in its architectural design. After all,

$6 \quad J N$ Klee, The establishment of the Rand Afrikaans University (RAU), A centerpiece in education of a modernizing Afrikaner livelihood (PhD, North-West University, 2017), pp. 20-51.

$7 \quad$ R Barnett, Being a university (London: Routledge, 2011), p. 1.

8 The process in the context of this article refers to the motives and elements that directed the thinking and actions taken to establish RAU.

9 UJ/RAU Archives, PJ Meyer Collection, File C1/1: Randse Afrikaanse Universiteit; Verslag van oorsese besoek, Geen datum, pp. 1-12.

10 UJ/RAU Archives, J Cronje Collection, File A 36/3: Interview by Mr J Cronje on 26 November 1981 at RAU with appointed architects Messrs W Meyer and J van Wijk, pp. 9-10.

11 UJ/RAU Archives, PMS von Staden Collection, File C 2, 12/3/1: Randse Afrikaanse Universiteit Ontwikkelingsplan, Geen datum, pp. 3-6.

12 UJ/RAU Archives, PJ Meyer Collection, File C1/1: Die beplanning van die Randse Afrikaanse Universiteit, 1968, pp. 1; 6. UJ library, Gedenkalbum van die opening van die RAU. 24 February 1968, pp. 12, 48-52. 
one of the leading objectives of the thinking underlying the new university was to assist in developing, educating and modernising white Afrikaans speakers on the Witwatersrand. This modernising would in practical terms mean introducing white Afrikaans-speaking students to new knowledge in different disciplines, ${ }^{14}$ knowledge that would contribute to their economic self-empowerment and advancement through the ongoing endeavour to build good relations between RAU, industry and business. This became clear during a symposium held at RAU on 20 and 21 February 1973, with the focus on economic advancement. ${ }^{15}$

In a speech made to the Afrikaans Chamber of Business Community in Johannesburg in March 1967, Viljoen explained that the founders of the new university had in mind the creation of a strong spirit and character within a defined vision and orientation towards achieving academic goals. ${ }^{16}$ As part of the dreams and considerations of the time, they also expressed their wish that RAU would embody the educational and cultural redevelopment and modernisation of the community it would "serve" - the white Afrikaans-speaking community on the Witwatersrand. RAU therefore had to become the central hub in educating and modernising the Afrikaner identity and securing its role in the South African economy. ${ }^{17}$

With the above introduction as background and the realisation that its founders seemingly wished to create an exceptional university, this article explores the relationship between modern architecture and innovative teaching methods as reflections of the philosophical ideals the founders envisioned. The article furthermore wishes to establish how this modern RAU contributed to the social, cultural and economic self-empowerment of the white Afrikaans speaker on the Witwatersrand in the period 1955 to 1975.

\section{THE "UNIVERSITY CHARACTER" OF RAU}

In order to understand the philosophical thinking inculcating the idea of RAU, it is important to understand a fundamental principle in its creation. This fundamental factor, identified by PJ Meyer and Viljoen - and which formed the philosophical foundation for RAU's establishment - was termed the Universities character,

$14 \quad$ G van N Viljoen, "The Afrikaans universities and particularism". In: HM van der Merwe and D Welsh (eds.), The future of the university in Southern Africa (Johannesburg: Martins Publishers, 1977), p. 172.

15 UJ library, RAU, Die taak van RAU as stadsuniversiteit, enkele hoogtepunte uit die vyfjaarfees van die RAU, 1968-1973, Toespraak Prof. G van N Viljoen - Die taak en opdrag van die RAU ..., pp. 60-61.

16 UJ/RAU Archives, Randse Afrikaanse Universiteit Collection, File A 34/1: Universiteit en gemeenskap; Toespraak van G van N Viljoen, Geen datum, p. 1.

17 S Dubow, A commonwealth of knowledge: science, sensibility and white South Africa, 1820-2000 (New York: Oxford University Press, 2006), p. 266. 
which was based on important lessons learned from universities internationally. ${ }^{18}$ Its basic principle was the single unit functionality of a university; the idea that this functionality stemmed from the close interrelationship between lecturer, student, research and university. For the founders of this new university it was important to understand what a university was as an institution, and what it was not, in order to fully understand what they envisioned for RAU in terms of the relationship between architecture and teaching methods.

For Meyer and Viljoen the university was not simply a place where knowledge would merely be transferred to students, neither was it a place where knowledge had to be generated or where it would be taught to prepare students for the workplace. Instead, Viljoen's philosophy for the university interwove these three objectives, emphasising their complementary nature. For Viljoen, a university's success would be determined by whether these elements were considered equally significant and related to each other. In a document by Meyer, entitled Universitas - op weg na die geheel as eenheid (on the way to totality as a unity), he identified the student as being the centre of the university institution, which was linked to the Universities character. For Meyer this element was very important ${ }^{19}$ as, according to him, the university through all its disciplines and courses was the way to knowledge. ${ }^{20}$ The university, through its unity in study, research and teaching had to prepare the student in his or her totality, with totality meaning the students' knowledge of the world, his psychological, cultural and religious being. The students had to be taught to engage with their world, to take charge and to take the lead. ${ }^{21}$

This realisation and its incorporation into the philosophical foundation for RAU would not in itself make the establishment of this university new and modern. What would make it new, however, was instilling the idea among the personnel and students that these elements needed one another and that the potential of these different elements would only be realised once interaction took place between them. It was therefore important for this idea to become part of the functioning of the new university, especially in its architectural and academic spheres. Only then would the true nature of the university, its aims and role in society be realised. ${ }^{22}$

\footnotetext{
18 UJ/RAU Archives, Johannesburg, PJ Meyer collection, File C 1/2: Universitas - op weg na die geheel as eenheid, Geen datum, p. 2.

19 UJ/RAU Archives, PJ Meyer collection, File C 1/2: Universitas - op weg na die geheel as eenheid, p. 2.

Ibid.

lbid., pp. 7-8

FIJ van Rensburg, "Sy visies vir die nuwe universiteit". In B Louw en F van Rensburg (reds.), Bestendige binnevuur. Perspektiewe op Gerrit Viljoen, p. 42.
} 
Klee \& van Eeden / Contemplating the approach RAU's founders...

As discussed above, Viljoen and Meyer took the lead among the founders of RAU in determining its philosophical vision and mission, ${ }^{23}$ which were fundamentally focused on the university's functioning as a unity. This philosophical vision and mission would be supported by new and modern teaching methods, housed in a modern and functional architectural structure that would further enhance and extend RAU's philosophical vision and mission.

\section{MODERN ARCHITECTURAL DESIGN AND INNOVATING TEACHING METHODS}

RAU's functionality principle in terms of administration, new teaching methods, relationship between lecturer and student, research and relationship between different disciplines, would be complemented by a modern architectural design. In this regard, the founders and planners of RAU took note of important elements in order to establish a truly remarkable university. These elements would emulate global trends, ${ }^{24}$ such as government policies regarding universities, the role of student numbers, and the interrelationship between university, government and society, to mention but a few. ${ }^{25}$ A further important element would be that of design. The planning of universities after World War II reflected dramatic advancement and a deliberate moving away from traditional and outdated building patterns and principles. This shift was stimulated by the development of new technological advancements in building techniques and styles in conjunction with newly available and abundant modern building materials and techniques.

The original design of RAU was consequently based on this availability of new building materials and techniques, the latter including the use of reinforced concrete, which would promote spatial flexibility, a factor that would accommodate the planning of small tutorial facilities. The design of RAU was furthermore based on thorough research, which entailed obtaining information regarding the latest developments in university planning and a vision that took future projections into account, ${ }^{26}$ including future expansion due to increases in student numbers and courses. Planning took into consideration these growths, but the major focus would always be on academic achievement. The physical

23 The terms vision and mission refer to what the founders wanted to achieve in terms of what this university stood for and what goals they envisioned for those it was established for.

24 J Elliott, Communities and their universities; the challenges of lifelong learning (London: Lawrence and Wishart, 1996).

25 J Currie and J Newton, Universities and globalization, critical perspectives (London: SAGE, 1998).

26 UJ/RAU Archives, JBZ Louw Collection, File A128/1: Randse Afrikaanse Universiteit - Fisiese beplanning, No date, p. 1; JN Klee, The establishment of the Rand Afrikaans University (RAU) ..., pp. 123-124. 
planning and establishment of RAU would focus on the expression of an idea, ${ }^{27}$ an idea both big and impressive. Meyer (founding member and inaugural chair of the RAU Council) had the following in mind regarding this idea and the importance of the interrelationship between academic and architectural planning: he wanted the academic planning to take a physical form that had to resemble a glove fitted to a hand. ${ }^{28} \mathrm{RAU}$ therefore had to be perfectly aligned in its planning and functionality; it needed to function as a single entity.

As indicated earlier, the modernising of the Afrikaner identity was the main driving force in the aims, planning and eventual establishment of RAU. The new university would moreover endeavour to expose white Afrikaans students to international and new, broader modern thought (new ways of thinking and approaching modern challenges), thereby achieving the modernising goal, it envisioned. ${ }^{29}$ Important therefore to the planning of RAU was the significance accorded to the interrelationship between academic and educational activities, and the functionality of the buildings in which these activities would take place. ${ }^{30}$ Indeed, the university's founders and planners attached great value to the closeknit relationship between the academic and philosophical ideals envisioned, and how the physical planning would complement and strengthen these ideals.

The planning process involved in RAU was characterised by three modern innovative elements. The first was that it would be an urban university with elements of a rural character. The second was the centralisation framework, which would embody the functionality and inner working of this university, and the third was the concrete symbolism, which would represent permanence. ${ }^{31}$ These elements will be discussed below.

\subsection{An urban university with a rural character}

The first element to be highlighted in a discussion of the architectural planning of RAU and its role in the university's modernising project was the decision to establish an urban university with a rural character. This was because it was believed that white Afrikaans students still had strong cultural links to their rural background and therefore had to feel at home in a university situated in the heart of Johannesburg. Rural characteristics, combined with impressive monumental

27 W Peters, "(Rand Afrikaans) University of Johannesburg, Kingsway Campus", Journal of the South African Institute of Architects, May/June 2011, p. 2.

28 UJ/RAU Archives, J Cronje Collection, File A 36/3: Onderhoud argitekte op 26 November 1981, tussen mnr J Cronje en die twee hoofargitekte van die RAU, nl. Mnre. W Meyer en J van Wijk, RAU, Johannesburg, p. 13.

29 SIGNUM, RAU 10 Jaar 1968-1978, p. 5.

30 Peters, pp. 2-3.

31 UJ/RAU Archives, PMS von Staden Collection, File C2, 12/3/1: Randse Afrikaanse Universiteit Ontwikkelingsplan (Totaalplan) Aucklandpark, Johannesburg, Verslag van argitekte se besoek aan oorsese universiteite, Geen datum, p. 3. 
buildings in a semi-circular form, complemented by a rolling landscape centring around an amphitheatre and fountains, would create a calming, yet inspiring, atmosphere. ${ }^{32}$ There had to be a natural relationship between city, university and rural landscaping, bringing together the old and the new, the known and the unknown. ${ }^{33}$

\subsection{Centralisation framework and functionality}

The second element was the framework within which the new university had to be realised. From the outset, it was made clear that a fragmented campus with buildings housing different faculties and scattered over a large area, with a design like that of other South African university campuses at the time, would not be an option. Centralisation was the main concept informing RAU's planning. ${ }^{34}$ The architectural planning needed a framework that would accommodate an unknown future. It needed, moreover, to be of a revolutionary nature. The new campus would represent an integrated town in a broad, decentralised network of global intellectual contact. ${ }^{35}$

For this reason, the ideogram for the RAU campus would make provision for immediate and planned long-term academic accommodation, which at that point was restricted to five types, namely flat-floor spaces for seminars, tutorials and discussions, raked-floor lecture theatres, offices for academic staff, laboratories and service areas. ${ }^{36}$ For Meyer and his co-founders the linear and orthogonal framework had severe drawbacks, one of which was that with future expansion and developments the physical limits of the university would be progressively distanced from any central or symbolic space. This would mean that the functionality of the building would be affected, because the time required to move from point $A$ to point $B$ would progressively become longer, thus affecting functionality and efficiency. For this reason Jan van Wijk, one of the architects, suggested that the two ends of the building be turned towards each other to create a "U"-shape. PJ Meyer (founding member) drew up a "U"-shape plan, giving birth to the horseshoe shape, which would eventually characterise the RAU building. ${ }^{37}$ This shape immediately improved the functionality of the architectural planning in that it increased the centralised activities. It also

32 UJ/RAU Archives, RAU-Rapport, 8 June 1975, p. 15; Klee, pp. 125-127.

33 UJ library, Gedenkalbum van die opening van die RAU, 24 February 1968. Speech by Dr N Diederichs, pp. 18-21.

34 B Schmahmann, Picturing change, curating visual culture at post-apartheid universities (Johannesburg: Wits University Press, 2013), pp. 6-7.

35 Wo Meyer, "Die idee agter die argitektuur". In: B Louw en F van Rensburg, Bestendige binnevuur, p. 71.

36 Peters, pp. 3-4.

$37 \quad$ Ibid., p. 4. 
complemented the envisioned harmonious relationship between academic activities and architectural layout. In addition, the seven-floor construction increased the centralised functional character, because it created the opportunity to bring departments and faculties closer together to enhance the crosspollination envisioned in academic activities. ${ }^{38}$

\subsection{Concrete and symbolism}

The third element important to RAU's physical planning was the vision of a massive concrete building, symbolising strength, permanence and modernity. The structure was complex, yet functional, in materialising the concept of a university based on a centralised philosophy in which contact, physical communication and togetherness were of great importance. The new and modern building was designed to enable contact through minimal effort and time spent moving from one area to the next. The symbolic value of the massive buildings, unyieldingly strong and secure, furthermore reflected the presence of the white Afrikaans speaker on the Witwatersrand, who was not only there to stay but also to contribute to society in a manner based on modern approaches and thinking. ${ }^{39}$ The massive walking areas, exhibition venues on the ground floor and imposing balconies, in addition to the impressive library, state-of-theart laboratories, and areas for student activities and learning, recreational, and shopping areas, also illustrated the modern approach taken in the establishment of RAU. 40 The horseshoe shape, according to Prof. HS Pelser (senior member of staff), at the time of the official opening of the new campus, was symbolic because it represented an invitation and openness to the outside community to partake in the activities of the university. ${ }^{41}$ This explanation stood in stark contrast to Dubow's and Herwitz's observation that the RAU campus resembled an urban laager in the centre of Johannesburg, ${ }^{42}$ a laager being associated with keeping the outside world at bay and isolating and protecting the white Afrikaans speaker from its influence. ${ }^{43}$

RAU's construction was indeed the expression of an idea, one shaped around six basic directives that PJ Meyer probably drafted on behalf (and in consultation with) the founders. The directives provided the architects with

38 UJ/RAU Archives, JBZ Louw Collection, File A 128/1: Randse Afrikaanse Universiteit - Fisiese beplanning, geen datum, pp. 1-2; I Wilkens and H Strydom, The Super Afrikaners (Johannesburg: Jonathan Ball, 1978), pp. 265-266.

39 UJ/RAU Archives, JBZ Louw collection, File A 128/1, p.2.

$40 \quad$ bid., pp. 2,4,8, 12-14,19.

41 UJ/RAU Archives, RAU-Rapport, 8 June 1975, p. 2.

42 S Dubow, A commonwealth of knowledge (New York: Oxford University Press, 2006), pp. 264265; D Herwitz, "Modernism at the margins". In H Judin and I Vladislavic, Architecture, apartheid and after (Cape Town: David Philip, 1998), p. 417; Schmahmann, pp. 6-7. B Schmahmann, pp. 6-9. 
some guidance regarding how this new and modern university would come to fruition. In the first place, the building had to resemble an Afrikaans Christian character. This had to be reflected in the greatness, strength and durability of the high-rise buildings. Secondly, it had to reflect new and improved ideas adapted to the needs of a new Afrikaans urban university that celebrated its community's heritage and yet was founded on modern initiatives drawn from around the world. Thirdly, it had to make provision for unrestricted architectural expansion and improvement. In the fourth instance, it had to be functional, displaying harmonious unity between the classical and the modern, and allowing the student to experience the Universities spirit envisioned for RAU. Fifthly, it would develop into an academic and cultural centre in which the Afrikaans artist would be given the opportunity to express and develop his or her talent. Finally, RAU had to keep up with modern developments academically and in architecture and construction, to embody ongoing development and progress in a modern and evolving global village. ${ }^{44}$ Interestingly, the administration building was not to be part of this philosophic educational symbolism.

RAU's architectural modern design and innovative teaching approach would ensure its centrality in the project of modernising Afrikaner identity, as will be outlined in the discussion below.

\section{INTERRELATIONSHIP BETWEEN MODERN DESIGN AND INNOVATIVE TEACHING OUTLOOK}

\subsection{Service through knowledge}

What would indeed make the university innovative, new and modern was instilling in staff and students the idea that the different elements of a university needed one another and that their potential could only be unlocked once closer Universities interaction was made possible. It was therefore important for the Universities interaction to become part of the functionality of RAU and especially of its academic operation. The Universities interaction would enhance and functionalise the university. Thus, the motto for RAU came about, phrased as Diens deur Kennis (Service through Knowledge). Service through knowledge firstly implied that the student would be educated in adequate preparation for his or her service in a career of choice. Secondly, it suggested that this preparation would coincide with the needs of the community and employers through the provision of in-house learning that always focused on the long-term skills requirements of

44 UJ/RAU Archives, PJ Meyer Collection, File C 1/2: Randse Afrikaanse Universiteit Geboubeplanning, Geen datum, p. 1. 
the country, and that the university's teaching and learning philosophy therefore had to be of service to the country as well. Lastly, service through knowledge implied that RAU would render a service to the country through ongoing research and teaching related to pressing and important issues. ${ }^{45}$

In conceptualising the Universities character, Viljoen identified four important elements that embodied his vision of the foundation and character of the new university. He referred to these as the four corner pillars, which, according to him, would guide the university on its mission and vision and form an integral part of the philosophy informing the task and role of the new university. ${ }^{46}$

The first pillar was to ensure the achievement of the highest standards of academics, science and knowledge. It had to strive to be the best. Not only would RAU require to be acknowledged locally by other universities, there also had to be international recognition.

The second task was to ensure effective character building. It would be the university's task to educate and develop successful students, but they also had to be properly shaped and trained to become future leaders. They therefore had to be equipped with idealism, the willingness to serve and the capacity to develop value systems that would help them cope in a changing country and world. ${ }^{47}$ These students could then play a major role in developing and modernising the white Afrikaans speaker on the Witwatersrand in particular and in South Africa as a whole.

The third pillar or task of the new university would be the advancement of the principle of belonging to a group (volksgebondenheid) - a characteristic attributable to its Afrikaans spirit and sound cultural and religious foundations. This task was in line with the political context of the 1960s and supported by the political structures prominent at the time, because it was based on the principle of exclusivity - a principle that evolved into inclusivity as politics in South Africa changed over time. ${ }^{48}$

The final fundamental stronghold contributing to RAU's role in society was the promotion of Christian values on all its operational levels. ${ }^{49}$ The university had to function based on Christian values and, in its modern and architectural impressiveness, represent something of the greatness of God and the Christian faith. This was reflected in the conscience clause adopted by the founders, based on the Constitution of South Africa at that point in time. ${ }^{50}$

$45 \quad$ FIJ van Rensburg, "Sy visie vir die nuwe universiteit", pp. 78-79.

46 Ibid., p. 123.

$47 \quad$ FIJ van Rensburg, "Sy visie vir die nuwe universiteit", pp. 123-124.

48 Schmahmann, p. 6.; Klee, pp. 115-116.

49 FIJ van Rensburg, "Sy visie vir die nuwe universiteit", p. 127.

50 UJ Library, Gedenkalbum van die opening van die RAU, 24 February 1968. Speech by Prof. G van N Viljoen - Welcoming of the parents of the students, p. 50. 
For RAU to be truly modern, logistically and infrastructural, it was important to ensure that the philosophical vision would be supported by new and improved teaching methods and systems. The impressive architectural design also needed to inculcate and extend new teaching methods to make them functional and meaningful.

\subsection{Innovative teaching methods to modernise Afrikaner livelihood}

As an urban university catering for students who, in most cases, would be first- generation university students, RAU had to consider that many students would initially require special assistance. Most of them would be day students commuting between home and classes - not residing in student accommodation provided by the university. Many of these students would also have individual personal, economic, social and educational challenges of which the university had to take note. Consequently, student advisory services were put in place. Although not unique to a university, these services were available right from the start, thus implementing what had been learnt from universities overseas.

Furthermore, the university founders, in their efforts to successfully implement innovative teaching methods, did not want students to simply become statistics, disappearing into the student body and the university structures. ${ }^{51}$ All these elements mentioned therefore had to be carefully considered and taken seriously right from the start to successfully implement the planned study methods and programmes within the context of a city university. It was therefore evident from the outset that all the planning - from student assistance and needs to study methods and programmes - had to take into consideration the urban character of RAU and its students. ${ }^{52}$ The reality was that the university would not be in the quiet suburban environment associated with that of, for example, the University of Stellenbosch or the University of Potchefstroom, or even in a setting like the quiet surroundings of the eastern suburbs where the University of Pretoria was located. RAU was to be situated right at the centre of the great city of Johannesburg, in an area characterised by a competitive environment of concrete and steel where people essentially operated in their own self-centred interest. The urban context contributed to the incorporation of a strong element of a rural layout of the campus grounds and its architectural planning. Here the modern and rural worlds would be juxtaposed, thus reflecting the historical rural

51 UJ/RAU Archives, Randse Afrikaanse Universiteit Collection, File A 34/1: Universiteit en gemeenskap: Toespraak van G van N Viljoen voor die Johannesburgse Afrikaanse Sakekamer, 21 Maart 1967, p. 4. 
heritage of white Afrikaans speakers who now found themselves in the new urban and, in most cases, alien Witwatersrand..$^{53}$

For this urban university to be successful and truly modern in its educational mission and vision, RAU had to ensure that it incorporated the teaching, research and practical elements outlined above with the inquiry-based learning process it envisaged for itself. This learning process also had to develop the total human being as outlined in the philosophical approach envisioned for RAU. It had to take cognisance of the student's educational background, cultural and language orientation, spiritual activities, historical background and engagement with the institution. ${ }^{54}$ It had to ensure - considering the international and local knowledge explosion occurring during the 1960 s and subsequently in the field of science and technology - that its programme offerings and teaching methods were always relevant. ${ }^{55}$

Furthermore, RAU needed to ensure that students were not only taught, trained and equipped for their various study fields and professions, but were also encouraged and inspired to continue with independent research even after graduating. ${ }^{56}$ For this reason, it was necessary to make certain that the important lecturing part of the study process was of excellent quality. The focus of the institution had to be on quality, functional teaching, learning, and outcomes, and not on simply driving an agenda to increase student numbers. ${ }^{57}$ To achieve this objective, the founding fathers envisaged a focus on research in order to acquire insight into knowledge itself. ${ }^{58}$ RAU not only had to be a new white Afrikaans university, but it also aspired to take the lead in the process of renewing teaching methods and learning at university institutions in South Africa..$^{59}$ Viljoen therefore formulated a new term, namely the futurological knowledge dimension, ${ }^{60}$ in which the practical outcome would go hand-in-hand with new study and teaching methods. It was hoped that this would contribute to the envisaged renewal of teaching and study methods at all universities in South Africa. The focus therefore had to be not only on what was studied and on how it should

53 UJ/RAU Archives, RAU-Rapport, 8 June 1975, p. 15.

54 UJ/RAU Archives, PJ Meyer collection, File C 1/1: Die beplanning van die Randse Afrikaans Universiteit, Geen datum, p. 10.

55 UJ/RAU Archives, Rand Afrikaans University collection, File A 34/1: Toespraak van G van N Viljoen, Johannesburgse Afrikaanse Sakekamer, 21 Junie 1967, pp. 6-7.

56 UJ/RAU Archives, PJ Meyer collection, File C 1/1: Die beplanning van die Randse Afrikaans Universiteit, pp. 6-7.

$57 \quad$ Ibid., p. 8.

58 UJ/RAU Archives, PJ Meyer collection, File C1/6: Die struktuur van die universiteit, Geen datum, p. 1.

59 UJ/RAU Archives, Anvil (Aambeeld), RAU: A return flight, 31(2), 2006, p. 6.

60 UJ/RAU Archives, J Cronje collection, File A 36/4: Prof G van N Viljoen - RAU vestiging, gebouekompleks en ontstaansgeskiedenis, 1969, pp. 1-4. 
be studied, but also on how that which was studied was determined, and the contribution it had to make to the learning process and to educational outcomes. ${ }^{61}$

In a speech in which he referred to the relevance of the university in general, PJ Meyer identified several elements required for a new university to be successful. These included: the need for the university to take note of the importance of the Universities idea; the relationship a university was to enjoy with the community it served; and the quality of its staff. ${ }^{62}$ In this regard, Viljoen's futurological knowledge dimension ${ }^{63}$ was of vital importance and enhanced Meyer's vision of the Universities idea. This reflected how the founders of RAU envisioned the role of the new institution, especially its modernising element. Over and above the normal elements of knowledge transfer, research and knowledge implementation, this element of futurological knowledge development would occupy an important place in RAU's functioning and teaching methods. In the context of the time, RAU's elements were modern, because they were based on updated research findings as well as well-researched teaching practices and not only on established practised methods, but implemented with a futuristic vision. This vision allowed for a continuous adaptation and renewal of these teaching practices.

Viljoen considered it vitally important that students be taught to think, to employ scientific methods and to engage in research to solve problems. What was also of vital importance would be to develop the skills through which projections could be made of future knowledge capability and needs. ${ }^{64}$ This would imply - it was hoped - that the student who studied at RAU would be taught to always be a step ahead in the search for new knowledge and in the way this knowledge was acquired and applied. ${ }^{65}$

\subsubsection{Multi-semester system}

For the learning process to be successful, a multi-semester system for teaching was introduced. At the time, South African universities had yearlong courses; RAU was the first to implement a semester system. This system was aimed at avoiding the traditional slow start of the academic year in February and the students' usual rude awakening at the end of the year in the form of a single final exam. Many students, imagining the year to be long, failed to work seriously right from the beginning of the year. Thus, in many cases, the old single semester system

\footnotetext{
61 Ibid., pp. 5-7.

62 Ibid., pp. 1-4.

63 Ibid., p. 7.

64 J Cronje collection, File A 36/4, RAU vestiging, geboukompleks, p. 6.

65 UJ/RAU Archives, Rand Afrikaans University Collection, File A 34/1: Talk by G van N Viljoen on the programme "Top Level" on Springbok Radio, "There are challenges in planning a new university", no date, p. 6.
} 
would determine the student's academic success. The new system, on the other hand, was introduced to ensure the optimum and economical use of the study period. The academic year would effectively be longer, and could therefore be used more productively. ${ }^{66}$

During a normal calendar year, reality entailed that faculties could stand empty for at least three months and this equalled academic time wasted. With the new system, this fallow period was reduced by the introduction of a third semester at the beginning of the year, before the first semester began. ${ }^{67}$ This ensured that students, who did not make progress or failed to apply themselves, could be sent away in the early part of the year rather than only at the end. ${ }^{68}$ The system also made provision for the implementation of two meaningful, yet distinguishable, semester units, allowing for a shift to a higher level of abstraction from the first to the second. Each semester would be characterised by two assessment opportunities and an exam at the end of that semester. ${ }^{69}$

\subsubsection{Teaching methods}

From the outset, the founders and local universities considered RAU to have taken the lead in an innovative South African teaching system that was both modern and effective. Was the teaching system new, flexible and creative, but it placed a high premium on responsible not only teaching that simply implied that lecturers had to adhere to their lecturing plan, content and tutoring. ${ }^{70} \mathrm{~A}$ standing teaching committee was established to provide support and was enriched by hosting regular symposia on the various facets of modern teaching.

The Standing Teaching Committee's establishment of high and modern teaching standards formed the bedrock of the modern teaching and learning process at RAU. The objectives of the committee were to ensure a high standard of teaching excellence through the delivery of quality teaching material. This process was based on the university's provision of a study document to each student, containing core notes, and known as a study guide, which would be revised every three years to ensure that its content kept up with the most recent knowledge developments in the various fields of science. The lecturer would moreover use the study guide to develop the subject matter in a conversational way, a method ensuring the student's orientation with regard to the study

66 UJ library, Gedenkalbum van die opening van die RAU, 24 February 1968. Speech by Prof G van N Viljoen - Welcoming of the parents of the students, p. 51.

67 UJ/RAU Archives, Anvil (Aambeeld), RAU: A Return Flight 31(2), 2006, p. 7.

68 UJ/RAU Archive, J Cronje collection - File A 36/4: Prof G van N Viljoen, Vestiging, geboubeplanning. Speech by Viljoen in front of the Municipality of Brakpan, 12 October 1969, titled Die Randse Afrikaanse Universiteit en die Munisipaliteit van Brakpan, p. 1.

69 UJ/RAU Archives, Anvil (Aambeeld), 31(2), 2006, p. 7.

70 UJ/RAU Archive, J Cronje collection - File A 36/4, Prof G van N Viljoen, Vestiging, geboubeplanning, p. 2. 
material and that the student could enhance his or her study through additional material obtainable from the library and, subsequently, available on the internet. ${ }^{71}$

In addition, students were required to attend all their classes because only then would it be possible for them to fully understand the subject matter. It was furthermore anticipated that the study process had to be characterised by a twoway conversation between the lecturer and the student. The learning process would not be characterised by the lecturer speaking and the student taking notes; rather, it had to be characterised by students preparing for lectures through the guidelines provided in the study guide and through required additional reading. The student would be able to engage with the content and the lecturer in an intellectual manner through a process of instruction, critical content analysis, questions and answers. ${ }^{72}$ The modernisation of the study process in terms of the content could be found in the provision of study material that was based on carefully selected content material in which the overall aim was not merely to provide fact after fact, but to also focus on method and fundamental principles. ${ }^{73}$

\subsubsection{Small Group Classes/Tutorials}

An integral part of the innovative teaching and learning process contained in the modern approach ${ }^{74}$ at RAU was the introduction of small-group/tutorial classes, now known as tutorials. Central to these classes was a dialogical element in which a closer conversation between the student and lecturer or facilitator could be achieved. Communication involved not only topic-specific content, but also related to problems students might experience with the subject matter, its compilation or even its approach. It was believed that this structure (and its implementing to ensure state of the art venues) would improve the quality of the study content and the way it was applied in the teaching and learning process. ${ }^{75}$ Group (tutorial) classes were not only introduced as a new method in the teaching process, but they were also intensively researched in symposiums dealing with group dynamics and studying the elements of group functioning. Its introduction and implementation were characterised by ongoing training for lecturers and especially student assistants. ${ }^{76}$ The Bureau for Higher Education established at RAU played an important part in conducting research on university systems

$71 \quad$ UJ/RAU Archives, Anvil (Aambeeld), 31(2), 2006, p. 7.

72 UJ Library, Gedenkalbum van die opening van die RAU, 24 February 1968. Speech Prof. G van N Viljoen - Welcoming of the parents of the students, pp. 53-55.

73 UJ/RAU Archives, Rand Afrikaans University Collection, File 34/1. Letter from Prof. G van N ViljoenDr 0 Geyer, 22 June 1967, pp. 4-5.

74 Randse Afrikaanse Universiteit: Die taak van die RAU as stadsuniversiteit. Enkele hoogtepunte uit die vyfaarfees van die RAU, p. 23.

75 UJ/RAU Archive, Anvil (Aambeeld) 31(2), 2006, p. 7.

76 AF Steyn en P Maree, "Akademiese vernuwing", in B Louw en F van Rensburg, Bestendige binnevuur, pp. 60-61. 
worldwide to enable RAU to keep up with what was happening internationally in teaching and learning practices. ${ }^{77}$ This bureau was also intensely involved in continuous guiding regarding the offering of tutorial classes. ${ }^{78}$

RAU was also a leader in physical planning. The first main element discussed above that formed an integral part in the planning of RAU, namely the Universities idea, was given creative and material meaning through the concept of centralisation integral to the architectural planning. This ensured that the philosophical ideals, such as Universities character, high academic standards, character formation and identity moulding, combined with new teaching and learning methods, could be creatively realised through a modern and functional architectural environment.

Already in the early years of RAU's existence, it became clear that innovative teaching and learning strategies, implemented by the founders as referred to above, contributed to RAU making good strides in modernising Afrikaner identity. In RAU's first academic year in 1968, 780 students registered for their studies: 29 registered for doctorates, 134 for master's degrees and honours, and 617 were first-year students. ${ }^{79}$ In 1972, this number increased to 1500 students of whom 465 graduated. At the graduation ceremony in April 1973, 317 students received their degrees and diplomas; in April 1975, 347 degrees were awarded, along with nine doctorate degrees. With 1138 degrees awarded by 1975, RAU had, in a very short period, made great strides in advancing the tertiary education of white Afrikaans speakers as well as contributing to their economic self-empowerment and advancement. ${ }^{80}$

\section{CONCLUSION}

In the contemplation on the approach of RAU's founders towards radically transforming Afrikaans speaker identity in taking economic responsibility, it was pointed out that the RAU's founders wanted to establish a university that would function as the expression of an [this] idea. This idea required specific educational needs and has culminated into expectations that would inform the education, development and modernisation of the white Afrikaans speaker on the Witwatersrand. The planning of this new, modern Afrikaans university was influenced by elements of Dutch and German university models, which represented Western university tradition. Research conducted during visits to universities around the world furthermore confirmed that the university idea

\footnotetext{
77 UJ/RAU Archives, Anvil (Aambeeld) 31(2), 2006, p. 8.

78 AF Steyn en P Maree, "Akademiese vernuwing", p. 61.

79 Booklet - The RAU after four years, Rand Afrikaans University, Public Relations Department, 1972, p. 5.

80 UJ/RAU Archives, RAU-Rapport 8(2), 1975, p. 22.
} 
was approached from a fresh angle and that common errors could be avoided in planning the establishment of RAU. For the founders, the new university had to be impressive, new and modern as part of the vision of transforming Afrikaans speaker identity. In order to reflect this specific philosophical perspective, the need for expressing some visible encounter in the university's architectural appearance, became part of the vision. This vision combined classical and modern elements, with centralization as principal part in the construction and building. Therefore, it was a clear moving away from the traditional-like way of scattering buildings to house departments and faculties over a large area. The "Universities principle", along with the "centralised principle" considered in the construction of RAU, eventually developed to its full potential and became the core around which the university functioned.

The philosophical vision and mission for RAU focused fundamentally on producing white Afrikaans students who would be educated and developed in their totality. New and modern teaching methods and systems became important elements of the new university, created by white Afrikaans speakers for the white Afrikaans speaker. RAU would be a university that would interpret and develop Afrikaans thought, critical and analytical thinking, and that would discourage the mentality of blind following. Furthermore, its educational focus would be on quality, functional training and on long-term outcomes. RAU's founders, working to create a new university among established universities, wanted to take the lead in developing and introducing new teaching methods and systems. They also sought international recognition. Radically modernising Afrikaans speaker identity had been the short- and long-term goal of this newly established university which had been perceived with mixed impressions in close-by communities and South Africa, but which is a debate perhaps for another day. 